http://dx.doi.org/10.4314/jae.v18i2.8

\title{
Constraints to Farmers' Labour Group Productivity in Eastern Kogi State, Nigeria
}

Edoka, M. $\mathrm{H}^{\star}$; Igbokwe, E. $\mathbf{M}^{\star \star}$ and Adejo, P. $\mathrm{E}^{\star}$.

* Dept. of Agricultural Economics and Extension, Faculty of Agriculture, Kogi State University, Anyigba

** Dept. of Agricultural Extension, Faculty of Agriculture, University of Nigeria, Nsukka GSM: 08062961759

E-mail: edokamatthew@yahoo.com

\section{Abstract}

Smallholder farmers in rural Nigeria face farm labour shortages and the need to find ways of dealing with this problem is therefore apt for food security and socioeconomic improvement. In an attempt to deal with this problem, Nigerians rural farmers constitute themselves into farmers' labour groups in other to meet their farm and non-farm labour needs. Apart from supplying farm and non-farm labour, farmers' organizations can also bring about farmer-tofarmer extension service to members and non-members. Farmers' labour groups in eastern Kogi State adopt this extension strategy to share ideas, network with other farmers within the social system and develop managerial capability to handle their farm problems. A total of 160 farmers' labour groups were identified by the researchers and all the labour groups were purposively selected. And from each of the identified farmers' labour groups, the heads of each group were selected, thereby giving rise to 160 respondents for the study. Structured interview schedule was administered on the respondents. Data collected was presented using frequency distribution, percentage and mean statistics. Researchers' findings revealed that, joint-problem solving ( $M$ $=2.8$ ), increased in farmers' managerial ability ( $M=2.7)$, promotion of knowledge-sharing $(M=2.5)$, and improved farmer-to-farmer networking ( $M$ $=2.4$ ) were some of the extension services rendered by farmers' labour groups to their members. In carrying out their activities, farmers' labour groups face a lot of challenges such as high poverty level of farmers $(M=3.0)$, low extension contact and poor health status of farmers ( $M=2.7$ respectively), and ruralurban migration $(M=2.6)$ among others. Policy statements that can improve the socioeconomic status of farmers, strengthen rural organizations and strong research-extension-farmer-linkage were suggested.

Keywords: Labour group, networking, rural-urban migration, small-holder farmers, Igala 


\section{Introduction}

The bulk of the food consumed in most cities in Nigeria come from rural farmers who employ indigenous techniques and family labour for most of their farm operations. The adoption of family labour does not really bring about the much needed economies of scale in food production. Before the advent of civilization, the extended family system played significant roles in the lives of the people. Members of the extended family lived and worked together and reinforced each other against the difficulties they had to contend with, especially farm tasks. Rural people are mostly smallholder farmers whose farmlands are small and scattered. Smallholders make a contribution not only to agricultural productivity but also to overall economic growth, by providing labour, capital, food, foreign exchange, and a consumer good market (Biggs and Biggs, 2001).

Agriculture cannot play this dynamic and wealth-creating role (food production) without an enabling policy environment, adequate institutions, and sufficient, well-targeted public and private investment. The experience of recent decades has been disappointing in this regard in a number of countries, particularly the least developed countries (LDCs), where investment has declined, rural poverty remains widespread and a very large share of the labour force is engaged in low-return agricultural work. The effects are being felt today with a large number of poorly educated rural youth with few skills and poor job prospects and a smallholder agriculture sector that cannot thrive due to lack of steady farm labour and support in terms of policy, infrastructure, inputs and investment. Clearly, to be successful, development of the rural sector must be part of a much larger process of social, economic and political development (ILO, 2005).

In consequence, the towns began to attract young men in their large numbers since it was in the cities that better social services and jobs were to be found. This drift of the rural population to the cities had begun with the resultant decline in rural farm labour force. Worthy of note too is the fact that, the Nigerian rural setting that provides the bulk of the food needs was neglected during the colonial era and has still not yet witnessed any major transformation in the post independence era (Raphael, 2002). The implication therefore is that, farming activities are therefore left to the aged people who are not energetic enough to take food production to the level needed. Studies have shown that available labour force in Nigerian rural areas comprise mostly of old people to the exclusion of young men and women between the active working age, thus having a negative impact on agricultural productivity (wikipedia.org/wiki/Labour). To meet their farm labour needs smallholder farmers constitute themselves into farm labour groups, thereby engaging in rotational farming among members. Saliu and Ojandage (2008) reported that, when farmers form themselves into group, it creates a sense of belonging, evolution of spontaneous reaction, group protection and pressure to conform; influences decisionmaking, discipline and cohesiveness among members. 
It is in view of the dearth of farm labour due to the exodus of young learned and energetic men to the urban centres that led to the initiation and formation of labour groups and/organizations by smallholder farmers in Nigeria's rural sector. A group like farmers' labour group is an assemblage of two or more human beings with common identity who are bound together in a formal relationship, and whose members interact together to satisfy complementary needs (Francis. et al, 2000). According to Odebode and Arimi (2008), the importance of farmers' labour groups or organizations in agricultural development of a nation cannot be overemphasized when considering the roles they play in agricultural production.

According to Aldrich and Marsden in Giddens (2010), people frequently band together to pursue activities that they could otherwise not readily accomplish by themselves as individuals. Rural farmers' labour groups are examples of farmers' organizations found in rural areas to provide mainly farm labour to members. The International Fund for Agricultural Development (IFAD, 2004) asserts that, 'group formation both fosters participation and enables the poor themselves to own their own development efforts', which improves targeting, sustainability, rural economic growth and revitalization.

With the failure of the Training and Visit ( $T \&$ \& ) extension approach (Nagel, 1997; Adedzwa, 2006) priority has been shifted to encouraging increased community and farmer participation in identifying common problems and solutions in an equal partnership with other stakeholders in agriculture such as researchers and extension workers. Many donor agencies and analysts called for a new extension paradigm that focuses on decentralization, demand-driven and increased farmer participation, hence the need to form farmers' labour groups to ensure adequate networking, knowledge-sharing and jointproblem solving. In this context, the extension worker will only serve as a facilitator by guiding and encouraging farmers in group to take joint initiatives (such as development of local innovations, exploitation of emerging opportunities, negotiation with authorities and many other processes) (Katz, 2002). Looking at the above scenario, the following research questions are therefore asked: What inform the formation of farmers' labour group? What potential do these labour groups have for farmer-to-farmer extension? And what productivity constraints do these farmers group faced?

It is in view of the aforementioned research questions that this study was designed to ascertain the constraining factors to farmers' labour group productivity in eastern Kogi State, Nigeria. Specifically, the study was designed to: identify the socio-economic variables of the farmers; ascertain perceived farmer-to-farmer extension potentials of farmers' labour group and, identify constraints to farmers' labour group formation and productivity. 


\section{Methodology}

The study was carried out in the eastern senatorial district of Kogi state which consists of 9 local government areas (LGAs) and two agricultural zones namely: Anyigba and Alloma agricultural zones. The area is located between Latitudes $6^{\circ} 30^{\prime}$ and $8^{\circ} \mathrm{N}$ and Longitudes $6^{\circ} 30^{\prime}$ and $7^{\circ} 40^{\prime} \mathrm{E}$ and covers a land area of about $13,665 \mathrm{Km}$ sq. According to 2006 National Census, the area has a population of about 1.9 million. The major language of the people is Igala but Bassa language is spoken as a minor language. The area is bounded to the north by Benue and Nassarawa states, Anambra state to the south, Enugu state to the east and River Niger to the west. The Igala ethnic group of Kogi state is found within the savannah belt having two distinct seasons: the wet season which begins in April and terminates in October, and the dry season which commences from November to March. Food crops such as yam, cassava, maize, beans, millet, etc. and cash crops such as oil palm, cashew, citrus, sugar cane etc. are grown for local consumption and export.

For purposes of data collection, all the LGAs were purposively used for the study. A total of 160 farmers' labour groups were identified by the researchers and were purposively selected. And from each of the identified farmers' labour groups, the heads of each group were purposively selected, thereby giving rise to 160 respondents for the study. Data generated was analyzed using descriptive statistics (frequency distributions, percentages and mean scores). Objective one (socioeconomic variables of respondents) was presented using frequency distribution and percentages, objective two (perceived farmerto-farmer extension potentials) was achieved using mean scores from a 3-point Likert type scale rating: to a great extent- 3 ; to a little extent $=2$, and to no extent $=1$. The attached values were summed up to have 6 , and then divided by 3 to have a mean score of 2.0. Mean score equal to or higher than 2.0 implied "to a great extent", while mean score less than 2.0 was considered as "to no extent". While objective three (constraints to farmers' labour group formation and productivity) were identified using a 3-point Likerttype scale of very serious $=3$; serious $=2$, and not serious $=1$. The values were added together to have a total sum of 6 , and the sum was divided by 3 to have a mean score of 2.0. Mean score greater or equal to 2.0 was considered as serious constraints and vice versa.

\section{Results and Discussion}

\section{Socio-economic variables of respondents}

The socio-economic characteristics of the respondents were presented in Table 1. According to the table majority $(75.00 \%)$ of the farmers were males with a mean age of about 51 years. Majority (45.63\%) of these farmers had primary education, though $30.00 \%$ had secondary education and only $3.13 \%$ of the farmers had tertiary education. The findings revealed that, $78.76 \%$ of the respondents are literate, and high or fairly literate farmers may be favourably disposed to accept and adopt farm technologies than the illiterate ones. Adejo, et al (2012) reported that the more educated a farmer is the more he/she becomes more civilized and informed about scientific agricultural practices. The table further revealed that most $(55.00 \%)$ of the farmers had a household size of between 1- 5 persons with a mean farm size of about 3 hectares and mean farming 
experience of about 37 years. This implies that, few labour hands were available despite the long experience in farm business, hence extra labour force will be therefore needed to take food production to next frontiers. This could probably be the major reason for the formation of farm labour groups among smallholder farmers in the study area.

Table 1: Socioeconomic variables of the respondents

\begin{tabular}{lll}
\hline Characteristic & $\%(\mathrm{n}=160)$ & Mean \\
\hline Sex & 75.00 & \\
Male & 25.00 & \\
Female & & \\
Age (Years) & 3.13 & \\
$20-29$ & 11.25 & \\
$30-39$ & 18.75 & \\
$40-49$ & 41.87 & \\
$50-59$ & 25.00 & \\
60 years and above & & \\
Educational level & 21.25 & \\
No formal education & 45.63 & \\
Primary education & 30.00 & \\
Secondary education & 3.13 & \\
Tertiary education & & \\
Household size & 55.00 & \\
$1-5$ & 36.25 & \\
$6-10$ & 08.75 & \\
10 and above & & \\
Farm size (Hectares) & 68.75 & \\
$1-3$ & 23.75 & \\
$4-7$ & 05.00 & \\
$8-10$ & 02.50 & \\
10 and above & & \\
Farming experience (years) & 00.00 & \\
$1-10$ & 01.25 & \\
$11-20$ & 09.39 & \\
$21-30$ & 32.50 & \\
1-40 years and above & 56.88 & \\
\hline Source: Fid Suvey, 2013 & & \\
\hline & & \\
& &
\end{tabular}

Source: Field Survey, 2013

\section{Farmer-to-farmer extension potentials of farmers' labour groups}

Data presented in Table 2 shows the extension potentials of farmers' labour groups in the study area. Majority $(M=2.8)$ perceived problem-solving potentials as a major skill learnt in farmers labour groups. Other skills perceived to have been developed were increased farmers' managerial capability $(M=2.7)$, promotion of knowledge-sharing $(M=2.5)$, improved farmer-to-farmer networking and encouragement of equal partnership between farmers, extension and researchers $(M=2.4$ respectively). In the words of Agbarevo and Obinne (2010), farmers' group/association or farmer-based extension model is farmerdriven extension delivery, in that local farmers group themselves serve as vehicle for 
knowledge sharing and diffusion of new ideas to members and the entire social system at large. The success of farmers' labour groups in most rural households could be attributed to their bottom-up philosophy which calls for involvement in decision making as against the formalized top-bottom approach of the Training and Visit (T \& V) of government extension service delivery. Farmers in group influence each others' behaviour, new agricultural practices can be easily adopted as the extension system now becomes more of farmers-led and as such, farmers' needs and interest receive greater attention as greater freedom of decisions are accommodated (Neuchattel, 1999; Saliu and Ojandage,2008).

Table 2: Mean distribution of respondents by perceived farmer-to-farmer extension potentials of farmers' labour groups

\begin{tabular}{|c|c|}
\hline Perception & Mean \\
\hline Strengthen farmers' problem-solving & $2.8^{*}$ \\
\hline Participation in decision-making process & 1.6 \\
\hline Increased farmers' managerial ability & $2.7^{*}$ \\
\hline $\begin{array}{l}\text { Encourage equal partnership between farmers, extension and } \\
\text { researchers }\end{array}$ & $2.4^{*}$ \\
\hline $\begin{array}{l}\text { Improved farmer-to-farmer networking } \\
\text { Promotion of farmers' capacity to adapt and develop farm } \\
\text { technologies }\end{array}$ & $2.4^{*}$ \\
\hline
\end{tabular}

\section{Constraining factors to farmers' labour organization and productivity}

Several factors constrained the effective formation and productivity of farmers' labour groups in most rural settings of Nigeria. Some of these factors are shown in Table 3. Results in the table show that high poverty level of farmers $(M=3.0)$, low extension contact and poor health status of farmers ( $M=2.7$ respectively), rural-urban migration $(M=2.6)$, low level of education and old age of farmers $(M=2.2$ respectively) and climate change $(M=2.1)$. Corruption and ignorant about labour laws $(M=1.5$ respectively), and religious differences $(M=1.4)$ do not constitute any threat to farmers' labour group formation and productivity. The Igala extract of Kogi state is known for peace and religious tolerance, hence the hatred the people have for religious crisis. Several publications and studies have shown details of the escalating poverty level in Nigeria between 1980 - 2009. According to National Poverty Eradication Programme (NAPEP) (2006), the average poverty incidence in Nigeria increased from 0.28 to 0.42 between 1980 and 1992 respectively, and by 1996, the situation worsened to an average of 0.66 . This then implies that, out of every 100 Nigerians, 66 are living below the poverty line of $\$ 1$ per day. The poor health status vis a vis farmers' age and the out-migration of ablebodied men to the urban centers could portend great danger to the agricultural sector as farming is left to the aged who may not have the needed strength for mass food production. Hence the need to form labour group which is the sure way to have a steady labour hands in farmers' farms. 
Table 3: Mean distribution of respondents by constraints to farmers' labour group productivity

\section{Constraint}

Lack of government support

Mean

Internal crisis

Low level of education

1.7

Low extension contact

$2.2^{*}$

Poor health status of farmers

$2.7^{\star}$

Old age of farmers

$2.7^{\star}$

Corruption

$2.2^{*}$

Religious crisis/differences

1.5

Rural-urban migration

1.4

Climate change

$2.6^{*}$

High poverty level

$2.1^{*}$

Exclusion from labour laws

$3.0^{\star \star}$

Ignorant about labour laws

1.7

Source: Field Survey, $2013 \quad{ }^{*}$ Serious constraints ${ }^{* *}$ Very serious constraints

\section{Conclusion and Recommendation}

The need for economies of scale in food production by rural farmers is identified to be the major fulcrum for food security and economic transformation. To meet this objective, rural farmers form farmers' labour group to close the labour gap that was created by ruralurban migration and the fast ageing labour hands in most rural Nigeria. Aside providing labour, farmers in group fosters joint-problem solving and other social assistance. The need to uphold this arrangement in our rural areas is therefore apt to move food production to the next frontiers. This study therefore recommends the following:

- Government and policy makers should strengthen farmers' organization like farmers' labour groups to enable then contribute meaningfully to the nation's economy

- Rural farmers' opinions should be should be respected and co-opted in agricultural policies and programmes

- Government support services such as soft loans, inputs, extension, mass literacy etc. should be adequately provided to facilitate farmers' productivity, and

- Rural infrastructure should also be given greater attention to reduce rural-urban out migration.

\section{References}

Adejo, P. E.; Edoka, M. H. and Adejoh, S. O. (2012). Indigenous practices and the challenges of climate change among small-scale farmers in Dekina Local Government Area of Kogi State, Nigeria. Proceedings of the $17^{\text {th }}$ Annual National Conference of the Agricultural Extension Society of Nigeria (AESON), held at University of Nigeria, Nsukka, 11-14 ${ }^{\text {th }}$ March, 2012, pp. 70-77.

Adedzwa, D. K. (2006). Research-extension-farmer linkage. A paper presented at the workshop on University of Agriculture Makurdi operational research plan, May 11-12, 2006, pp. 1-15 
Agbarevo, M.N.B. and Obinne, C.P.O. (2010). Elements of rural sociology and extension. Teo Publishers, 33 Peter Okoye St. Enugu, Nigeria, pp. 8-9.

Biggs, F. and S Biggs (2001). "Evolving themes in rural development 1950s-2000s." Development Policy Review, 19(4).

Francis, T.; Agapi, S. ans Xinshen, D. (2000). Rural labour migration, characteristics and employment patterns: A study based on China's agricultural census. Trade and Microeconomics Division (TMD), International Food Policy Research Institute (IFPRI) Discussion Paper N0. 63, Washington DC, 20006, USA.

Giddens, A. (2010). Sociology (6E). Wiley and Sons Inc. pp. 783-791. International Fund for Agricultural Development (IFAD) (2004). IFAD recommendations for eliminating rural poverty and achieving food security. $36^{\text {th }}$ World Farmers' Congress, $29^{\text {th }}$ May- $4^{\text {th }}$ June, 2004, Washington DC.

International Labour Organization (ILO) (2001). Safety and health I agriculture. ILO Labour Law, No. 184. ILO, Geneva.

Katz, E. (2002). Innovation approaches to financing extension for agricultural and national resources management. Switzerland, LBL, SWISS center for Agricultural Extension, p.135.

Nagel, U. J. (1997). Alternative approaches to organizing extension. In: S.E. Swanson, R. P. Bentz and A. J. Sofranko (eds). Improving agricultural extension: $A$ reference manual. Food and Agriculture Organization (FAO) of the United Nations, Rome, Italy, pp. 13- 20.

Neuchattel, G. (1999). Common framework on agricultural extension. Neuchattel Group, Paris, p. 2. www. Odi.org.uk/rpeg/efen.pdf/ Accessed June, 2007.

National Population Commission, Lokoja, 2006.

National Poverty Eradication Programme, 2006.

Raphael, N.E. (2002). Constraints to living standard measurement I rural Nigeria and implications for information management in food policy. Nigerian Journal of Rural Sociology, Vol. 4(1), pp. 43-52.

Saliu, O. J. and Ojandage, A. I. (2008). Modern leadership theories and sustainable farmers organizations in a liberalized economy. Nigerian Journal of Rural Sociology, Vol. 8, No. 2, pp. 33-40.

wikipedia.org/wiki/Labour 